\title{
Planning Permanent Air Raid Precautions: Architecture, Air War and the Changing Perceptions of British Cities in the late 1930s
}

\author{
‘Prepare! Prepare!' does not do for a slogan. No more does 'business as usual.' [...] No slogan works. ${ }^{1}$
}

At the height of the Munich crisis in autumn 1938, when war seemed imminent, the hurried digging of miles of shallow trenches in public parks exposed the limits of government preparations for air raids. ${ }^{2}$ Following the crisis in the Sudetenland, the problems of negotiating the competing calls to 'Prepare! Prepare!' while maintaining 'business as usual', were brought into close focus. E.M. Forster described the condition created by the contradictions of preparing for war while pursuing peace as 'The 1939 State'. In his 1939 essay, subsequently republished and renamed, 'Post-Munich', Forster wrote that such slogans urging now preparation for war, and now business as usual, had lost all meaning. 'Only heaven and hell are stable', he wrote, and the 'post-Munich world' was decidedly mixed. ${ }^{3}$ This article investigates how in this 'mixed state' government preparations for war came to be increasingly conceived as essential elements in ordinary peacetime planning and development. It asks how the boundaries between peace and war, and thus military and civilian, began to be dissolved in this context. In order to do this, it examines the interactions between architects, planners and government officials about how the design of cities and buildings might change in an age of air power.

A growing literature on air power between the wars has highlighted how the fear and expectation of future war and future air raids influenced societies and governments. ${ }^{4}$ Literary and filmic imaginaries were created and read in dialogue with official pronouncements about the likely

\footnotetext{
${ }^{1}$ E. M. Forster, 'Post-Munich', in Two Cheers for Democracy (London, 1951), 34. The essay was first published as 'The 1939 State', New Statesman and Nation (10 June, 1939).

2 John Baker, Enterprise versus Bureaucracy: The Development of Structural Air-Raid Precautions during the Second World War, (Oxford, 1978), 4.

${ }^{3}$ Forster, 'Post-Munich', 34.

${ }^{4}$ Tami Davis Biddle, Rhetoric and Reality in Air Warfare: The Evolution of British and American Ideas About Strategic Bombing (Princeton, N.J., 2002); Andrew Barros, 'Razing Babel and the Problems of Constructing Peace: France, Great Britain and Air Power, 1916-28', English Historical Review, 126 (2011), 75-115; Brett Holman, 'The Shadow of the Airliner: Commercial Bombers and the Rhetorical Destruction of Britain, 1917-35', Twentieth Century British History, 24 (2013), 495-517; Susan Grayzel, At Home and Under Fire: Air Raids and Culture in Britain from the Great War to the Blitz (Cambridge, 2011).
} 
effects of a future air war. ${ }^{5}$ While these studies have cast light on the interconnectedness of the culture and politics of the period, it is important not to neglect the more fundamental consequences of the changing understanding and definition of war. The cultures of air war and bunkers have been examined in social, cultural, and political histories, but currently the materiality of this new type of infrastructure, and its place in cities, has not been analysed. ${ }^{6}$ Such an approach engages more broadly with questions about the impact of war in twentieth century Britain, and builds on David Edgerton's critique of histories which have presented the Second World War as 'a powerful motor of peaceful constitutional progress'. ${ }^{7}$ A focus on how the expectation of war impacted upon perceptions of the built environment, a crucial part of modern industrialized societies, offers a novel way to discuss the broader consequences of war and air power. ${ }^{8}$ It takes the warfare state and examines how it was written into plans for the civilian space of cities in anticipation of war. Going further, it attempts to ask how military and civilian concerns in a period of pre-war found a common language in planning.

Planning is concerned with an uncertain future, or as Michel Foucault wrote, 'a good town plan takes into account precisely what might happen. ${ }^{9}$ But, as Frank Mort has argued, a crucial element in planners' perceptions of urban futures is fantasy. ${ }^{10}$ Just as utopian imaginaries inspired planners, so too did the fearful expectation of future war. Air raids were a powerful motivator for

${ }^{5}$ T.H.E. Travers, 'Future Warfare: H.G. Wells and British Military Theory, 1895-1916', in Brian Bond and lan Roy (eds), War and Society: A Yearbook of Military History (London, 1976), 67-87; Martin Ceadel, 'Popular Fiction and the Next War, 1918-1939', in F. Gloversmith (ed.), Class, Culture and Social Change: A New View of the 1930s (Brighton, 1980), 161-184; Sven Lindqvist, A History of Bombing, trans. Linda Rugg (New York, 2001); Paul K. Saint-Amour, 'Air War Prophecy and Interwar Modernism', Comparative Literature Studies, 42 (2005), $130-161$.

${ }^{6}$ An exception is Jean-Louis Cohen, Architecture in Uniform: Designing and Building for the Second World War (Paris; London, 2011).

${ }^{7}$ David Edgerton, Warfare State: Britain, 1920-1970 (Cambridge, 2006), p. 287.

${ }^{8}$ Most of the work on cities and war has focussed on reconstruction, and the two World Wars are largely absent from the major urban history of modern Britain, Martin Daunton (ed.), The Cambridge Urban History of Britain, Vol. III: 1840-1950 (Cambridge, 2000). Some recent work has begun to address the relationship between cities and war in the twentieth century, see Goebel and Keene, (eds), Cities into Battlefields; Marcus Funck and Roger Chickering, Endangered Cities: Military Power and Urban Societies in the Era of the World Wars (Boston, 2004).

${ }^{9}$ Michel Foucault, Security, Territory, Population: Lectures at the College de France, 1977-78, trans. Graham Burchell, (ed.) Arnold Davidson (Basingstoke, 2007), 20.

${ }^{10}$ Frank Mort, 'Fantasies of Metropolitan Life: Planning London in the 1940s', Journal of British Studies, 43 (2004), 120-151. 
planners in much the same way as more optimistic visions. It is the interaction of unpredictability, fantasy and anxiety that shaped the imagined futures sketched out by architects and planners in this period.

Plans are only ever a vision of a possible future, but if in urban planning, as Guy Ortolano states, 'expectations about the future were filtered through assumptions about the present' then the case of plans for permanent air raid precautions (ARP) is instructive. ${ }^{11}$ It illustrates how expectations of future air war impacted upon contemporary perceptions of the built environment and the plans for urban futures, while highlighting how urban space and expert knowledge were brought into war planning during peacetime. By analysing how policymakers and professionals concerned with the future of cities understood ARP as an element within more general considerations for future urban and industrial development, this article engages with the question of how the fear of air raids was, in Lewis Mumford's words, 'fixed into routine'.12

\section{Air Raids as an Architectural Problem}

In June 1936 Colonel William Garforth spoke at the Royal Institute of British Architects (RIBA) in London. His address, subsequently published in the August issue of the Journal of the RIBA, detailed the official understanding of the effects of future air raids, and outlined current preparations. ${ }^{13}$ Garforth was a member of the Air Raid Precautions Department which had been established in the Home Office in May 1935. ${ }^{14}$ His address reflected how the government increasingly placed ARP in the public eye and was part of a series of lectures on 'the principles of protection in air raids' to factories owners, business organisations and local chambers of commerce. ${ }^{15}$ The Department was an extension and formalisation of the sub-committee that had reported to the Committee of Imperial Defence since $1924 .{ }^{16}$ With a formal position in the Home Office, it gained a prominent role in governmental planning and preparation for a future war. The move reflected the shift in the focus of discussions about air war to the protection of British cities; the increasingly public official discussions of the dangers of air raids; and, perhaps most significantly, the positioning of air raid precautions within an ostensibly civilian peacetime government department.

\footnotetext{
${ }^{11}$ Guy Ortolano, 'Planning the Urban Future in 1960s Britain', Historical Journal 54 (2011), 494.

12 Lewis Mumford, The Culture of Cities $7^{\text {th }}$ ed. (London, 1953), 275.

${ }^{13}$ Col. William Garforth, 'A Few Principles of Protection in Air Raids', Journal of the RIBA 43.18 (8 Aug. 1936), 985-989.

${ }^{14}$ Grayzel, At Home and Under Fire, 201.

${ }^{15}$ Garforth, 'A Few Principles of Protection', 985.

${ }^{16}$ For the establishment of the Sub-Committee and their first report which emphasized the 'moral effect' and the inevitability of civilian casualties see Grayzel, At Home and Under Fire, 124-138.
} 
The Department's first major public act was to issue a memorandum on measures to be taken for ARP by central government, industrial and commercial employers, householders and local authorities. ${ }^{17}$ The circular was made publicly available before being published in The Times in July. ${ }^{18}$ The government's interest in ARP had led them to approach technical experts to offer advice on passive defence. The professionals who might be involved in the design and building of the structures that could shield civilians from bombs were increasingly preoccupied with, at times highly politicized, debates about ARP. ${ }^{19}$ Architectural journals increasingly discussed structural precautions and called for more clarity from the government. The voice of the architect in ARP debates had been officially established when the structural precautions committee was formed in 1935, and since November 1936 a section of the Journal's review of periodicals was devoted to discussions of ARP in other journals across the world. ${ }^{20}$ It was in this context that Garforth spoke before a full Portland Place and began by stressing that the air raids experienced in the last war would bear little resemblance to those to come in the next.

He outlined the expected effects of a variety of bombs, and appealed to architects to take up the question of structural precautions. While emphasising that he hoped precautions would prove unnecessary, the belief that there would no more than seven to ten minutes warning of a raid, meant that schemes ought to be prepared in any case..$^{21}$ In the discussion after Garforth's speech, anxiety about air raids was articulated through support for thorough architectural studies of structural precautions. Throughout the discussion, there was a sense of urgency, and of the importance of instilling a national mentality which went beyond 'air-mindedness', to 'air raidmindedness'.22 The arguments that structural precautions needed to be made in peace due to the speed of a potential attack, cast ARP as a fixed element in architectural thinking and design for the future. The preliminary discussions between the ARP Department and the RIBA in 1936 were

\footnotetext{
${ }^{17}$ The National Archives, London (TNA), Cabinet Papers (CAB) 24/255, R.R. Scott, Air Raid Precautions Memorandum, June 1935.

18 Joseph S. Meisel, 'Air Raid Shelter Policy and its Critics in Britain before the Second World War', Twentieth Century British History, 5 (1994), 304; The Times, 11 Jul. 1935, 9. For a discussion of the press response to the circular see Grayzel, At Home and Under Fire, 201-205.

${ }^{19}$ For the shelter debate see Meisel, 'Air Raid Shelter Policy'.

20 The papers of the structural precautions committee are in TNA, (Home Office) HO 211/1-6. British architects generally took a more central role in debates over the protection of civilians from air raids, than elsewhere in Europe where these discussions were also being held, Cohen, Architecture in Uniform, 161.

${ }^{21}$ Garforth, 'A Few Principles of Protection', 989, 987.

22 Thomas Scott and R. Coppock, quoted in ibid., 989, 990.
} 
extended two years later when they organized a full conference on structural precautions against air raids.

Over three days in June 1938, the RIBA hosted the conference at Portland Place. At the Home Office's request, attendance was open to all registered architects, with local authorities invited to send representatives. In the introduction to the subsequent publication in the Journal of the lectures and discussions, which extended to fifty two pages, the conference was described as 'the biggest task ever laid on the RIBA, or the profession by the government of this country'. ${ }^{23}$

On the first day of the conference, architects Thomas Scott and Eric Bird outlined the key issues facing architects with regards to passive defence. The consensus was that architects must use their skill and expertise in any way possible to attempt to combat what Scott described as 'the hideous and tremendous forces of air attack as depicted by the popular Press'. The holding of such a large conference in peacetime was indicative of the increasingly mainstream position of ARP in public discourse, particularly in relation to the future development of technology and the built environment. Architects at the conference situated structural precautions against bombardment as central to the future of architecture. Scott stressed in his speech how 'peacetime precautions' were clearly preferable to 'emergency measures' rushed into place when a war was declared. Since air power had superseded older notions of war, it could not be assumed that there would be time to prepare. One of the consequences of the speed and unpredictability of attack that air power enabled was that the threat may rise or fall in line with the contemporary political and international circumstances, but it would never be truly diminished. Architects took account of this by bringing ARP into more ordinary considerations in building design.

Scott argued that the inclusion of structural precautions in design should be 'a new and permanent factor in the design and construction of buildings'. This could be done, he argued, 'without detriment to their artistic quality and efficiency'. The assertion of the permanence of ARP, reflected how air power had ushered in an era of constant danger and vulnerability. Scott's assertion later in his speech that the problems of structural precautions were strictly architectural, and were not an 'engineering or military problem', further demonstrated that ARP was considered an ongoing civilian task with a potential technological or design fix. ${ }^{24}$ The inclusion of structural precautions against air attack was recasting the way the aesthetic values of buildings were understood. In his address on the principles of structural ARP, Eric Bird described 'the ideal building from an ARP point of view', as:

\footnotetext{
${ }^{23}$ 'Journal', Journal of the RIBA, 45.16 (27 Jun. 1938), 780.

${ }^{24}$ Thomas Scott, 'Air Raid Precautions as a Problem for the Architect', Journal of the RIBA 45.16 (27 Jun. 1938), $783,786$.
} 
one of which the structure is a steel or reinforced concrete frame having light panel walls or large areas of glass and fully fire-resisting, provided its occupants can all be contained in a properly designed basement shelter, preferably of reinforced concrete.

Bird seems to have described an archetypal modernist building. The reinforced basement shelter beneath light walls and much glass, would, he suggested, offer good protection to residents. Steel architectural skeletons overlain with light walls and glass would fall without crushing the people safely ensconced in the basements below. Bird also highlighted the peacetime benefits of 'air raidminded' building, suggesting that the provision of reinforced basements could be used for recreation rooms, communal laundries and bicycle stores. He referred particularly to Department Stores and hoped that more business owners would follow the lead of those who saw ARP as a type of insurance against future disruptions to business. ${ }^{25}$

The discussions at the conference suggest that RIBA architects were coming to view ARP as a largely civilian matter, something which needed to be incorporated alongside other considerations in the design and construction of new buildings. The conference at the RIBA was an example of how ARP was being separated from other defence measures, and the boundaries between civilian and military planning were disintegrating. In town planning, established urban problems, principally congestion and slum living, were reframed by the threat of air raids in a way which presented solutions to vulnerability as sensible urban development policy regardless of the immediate threat of air raids. These debates grew louder after the crisis of 1938 as the focus on ARP and civil defence intensified.

\section{Crisis, Civil Defence and Town Planning}

A government review of civil defence measures taken during the Munich crisis exposed widespread uncertainty about the predicted effects of future air raids and how best to counter them. ${ }^{26}$ The government's view of modern war which could begin 'with little or no warning and without a declaration of war', meant that sufficient measures must be taken in peacetime to limit Britain's vulnerability to an unforeseen attack. The unpredictability of war, together with the unprecedented reach of air forces, and the legitimisation of cities as targets, contributed to the government's belief that 'from the first moment of hostilities the life of every section of the community may be gravely

\footnotetext{
${ }^{25}$ Eric Bird, 'Some General Principles of Structural A.R.P.', Journal of the RIBA 45.16 (27 Jun. 1938), 788--789.

${ }^{26}$ TNA, Ministry of Transport (MT) 50/56, Committee of Imperial Defence, 'Review of Precautionary Measures (Civil Defence) Taken During the Czechoslovakian crisis, Sept. 1938', 14 Nov. 1938.
} 
affected'. Whereas in previous years emergency measures could be left to improvisation in the days before and the early stages of a conflict, the report asserted that in an era of air power the completion of civil defence measures may 'have to be carried out in full in peace'. ${ }^{27}$ The need for a rapid transition between a peace and a war footing was such that large-scale civil defence preparations, with ARP high amongst them, must be in place and ready to set in motion at a moment's notice. The whole notion of a distinction between peacetime and wartime had been troubled by the potential immediacy of air war and the reach of the bombers. ${ }^{28}$

As the need for a rapid transition between peace and war became a dominant concern following the 1938 crisis, it followed that the exigencies of war must bleed into the structures of everyday life and government in peace. But as the debates amongst architects, the government, and the military at the RIBA demonstrate, this process was underway before the Munich emergency and the evident failings in civil defence preparations it exposed. The 1938 crisis did, however, focus the minds of parliament on ARP and the new language of civil defence. After the crisis, various departments were asked by the Committee of Imperial Defence to quickly produce reports before a conference was held to discuss the findings. The review drew three primary conclusions: a new approach needed to be taken to the issue of secrecy; the responsibility for civilian evacuation should be transferred to the Minster for Health; and plans for the movement of the government in the event of war should be re-considered. ${ }^{29}$ The recommendation that secrecy levels around war preparations should be lowered reflected how air power was fundamentally transforming government approaches to, and understandings of, the boundaries between war and peace, military and civilian.

The report argued that secrecy was a major barrier to the cooperative functioning of civilian and military planning, and had a significant impact on both 'the planning work and the efficiency of the measures themselves in a crisis'. ${ }^{30}$ But the lowering of the borders of secrecy only contributed to an ongoing process of amalgamation and coordination. While debates continued over air war strategy and its effectiveness, public calls for air raid shelters and increased government focus on defence at home informed the development of new civil defence policies. The preparations for passive defence against air raids represent a clear demonstration of the conflicts within government and the resonance fears about aerial war had on the perception of the future of cities. The report

\footnotetext{
27 TNA, MT 50/56, 'Review of Precautionary Measures', 4-5.

${ }^{28}$ This is an idea discussed more broadly in Mary Dudziak, War Time: An Idea, it's History, it's Consequences (Oxford, 2012).

${ }^{29}$ TNA, MT 50/56, 'Review of Precautionary Measures', 7.

30 Ibid., 4.
} 
into the civil defence response to the crisis reiterated a key theme from the architectural discussions, namely the importance of having a national civil defence infrastructure that enabled a rapid transition from peace to war. A national protective infrastructure meant structural precautions built permanently into cities, and an effective bureaucracy to coordinate offices across the country. Attempts to create such a national ARP organisation had been developing before the crisis.

In the first months of 1938 the ARP Department had been enlarged and reorganized. New offices were opened in Leeds, Birmingham, Edinburgh, Newcastle, Liverpool and Nottingham in January 1938, with more opened in Reading, Bristol, Glasgow, Cambridge and Cardiff in the following months. ${ }^{31}$ In order to justify the expenditure that the ARP Department called for, the government, as the RIBA architects had in their 1938 conference, explained the need for ARP measures in terms of the additional peacetime benefits and assurances they would provide. Successful and rigorous planning would be essential if the cities were to survive air raids. Roads and transport infrastructure were of particular importance as they would enable people and materials to move quickly into and out of threatened cities.

In March 1939 former Minister of Transport and then London County Council leader Herbert Morrison, a strong supporter of planning who could claim the creation of the London Passenger Transport Board and the Metropolitan Green Belt amongst his successes, opened an exhibition at the RIBA on road architecture. Morrison stressed his belief that road schemes were 'the backbone of town planning', and that the role of the modern architect was not building luxury buildings. 'The architect', Morrison said, 'has functions which are far beyond those considerations'.32 If planning were to be successful, Morrison argued, the vested interests that had held it back for so many years must be swept away. The congestion in the cities that he sought to alleviate through planning was placed explicitly and fearfully in the context of aerial war by one of the posters from the exhibition, which was subsequently reproduced in the journal. The poster showed bombs falling onto a patch of land drawn as a building with brick exterior walls, while people fled away from the centre.

\section{INSERT FIGURE 1. HERE}

Figure 1. 'National Emergency Creating Problems', Poster from RIBA Exhibition March 1939, Journal of the RIBA 46 (20 March 1939), 509. Credit: RIBA Library Photograph Collection.

The subtitle to the vivid imagery of smoke and fires rising up beneath a steady stream of bombs, 'THE DANGER OF CONGESTED AREAS', reflects how congestion in cities, which had long been

\footnotetext{
31 Terence O'Brien, Civil Defence (London, 1955), 113.

${ }^{32}$ Herbert Morrison, 'Road Architecture - The Need for a Plan', Journal of the RIBA 46 (20 Mar. 1939), $508,506$.
} 
criticized on the ground of hygiene, efficiency, and the germination of slums, had been reconfigured by the growth of air power. The same congested areas that had caused concern in the nineteenth century, which Eric Bird described as 'the rotten old cores of towns consisting of huddled buildings of poor construction', were re-designated as the most vulnerable points to air attack. With the expectation of war hardening, Bird argued at the end of 1938 that 'mankind would even bless the threat of air-bombing' if it had forced them to rebuild their towns, 'with widely-spaced multi-floor framed buildings in the centres and gardens suburbs on the outskirts'. ${ }^{33}$ The fear of imminent war only made clear and urgent the already well-rehearsed drawbacks of such thickly populated urban areas. $^{34}$

The gravity of ARP lent weight to a scientific approach to design, and the self-image of architects and planners as essential to the future of the country. The crisis had shown how urgent planning for defence was. The task for architects and planners was now, as William Holford said in a speech to the RIBA in December,

To plan the fabric of civilian health and civilian protection, to plan for education and housing, to plan for large-scale evacuation (not only as regards camp accommodation but for the whole altered pattern of daily life which an emergency might create), to plan new towns and cities - in a word to plan the militant peace which to-day is the only alternative to a barbarous war. ${ }^{35}$

The 'militant peace' which Holford envisaged represents the co-ordination of town planning, ARP and civil defence, the normalisation of emergency measures, and the acknowledgement that the old ideas of war and peace had been irrecoverably changed by the development of air power. Holford's views were representative of those who believed that architecture and planning had an essential part to play in the defence of the nation from air attacks.

The debates about architecture and planning for defence were not confined to the specialist press. An article in Picture Post in January 1939 entitled 'A Realistic Plan for ARP' addressed the problem of shelters and extended the analysis to what town planning could achieve in peace and war. ${ }^{36}$ The article first highlighted the vulnerability of built-up urban areas to bombing, with pictures of ruined buildings in Spain, an aerial photograph of tangled streets in London captioned 'A Perfect

\footnotetext{
33 'ARP - The informal meeting', Journal of the RIBA 46 (9 Jan. 1939), 240.

${ }^{34}$ Sidney V. Pearson, London's Overgrowth and the Causes of Swollen Towns (London, 1939), 9.

${ }^{35}$ W. Holford, 'The Next Twenty Years', Journal of the RIBA 46 (5 Dec. 1938), 171.

${ }^{36}$ The article was anonymous, part of a series 'prepared by an authority on air bombardment with the advice of a number of experts', 'A Realistic Plan for ARP', Picture Post, 21 Jan. 1939, 54.
} 
Target', and a picture of back-to-back terrace housing captioned 'A Modern Death Trap'. ${ }^{37}$ The article then proposed how town planning could relieve the pressure on cities in a way that would be beneficial in both peace and war. The layout of housing, the provision of open space, and the organisation of a road network that would not be disabled by congestion, or by air raids, were cited as key elements in a successful and modern town plan. ${ }^{38}$ The mutual benefits for cities in peace and war were a central part of the discussions about planning and the fear of air raids. The drawing together of peace and war in planning discourses was part of Holford's idea of a 'militant peace' which dissolved the barriers between civil and military visions of the future of cities. ${ }^{39}$

The government and town planners did not fail to notice the potential for ARP and town planning to work hand-in-hand to build a new, decongested, less vulnerable Britain. The ARP Department consulted with both architects and town planners on how their interests could coalesce. The Chief Technical Officer of the ARP Department, Alexander Rouse, who would later become the Chief Engineer in the Ministry of Home Security, was a member of the Town Planning Institute. At a meeting of the Institute, Rouse stated that there was 'only one field in which A.R.P. and modern thought go together and that is the field of town planning'. Rouse supposed that town planners, with the gift of prophecy, had arrived at ideals which were 'to a large extent the ideals of planning for A.R.P. ${ }^{\prime 40}$ The ARP Department and the Town Planning Institute agreed that the concentration of population in urban areas was 'bad from both points of view'. Dispersion was the fundamental principle governing ARP planning and the creation of 'grouped communities set in an unspoilt Countryside' was the aim of town planners. One of the examples given for the potential of a common approach to achieve common aims was the introduction of small parks, playing fields and allotments, which were described as both 'sound planning and [beneficial] to safety'. ${ }^{41}$ The question of passive defence against air raids was presented as both a feature of design and planning that was necessarily becoming embedded in practice, and as a solution to the historic problems of congestion and poor quality building in the cities. The planning image of cities had been altered by the

\footnotetext{
37 Ibid., 54-55.

38 Ibid., 56-58.

${ }^{39}$ These ideas discussed in a review of architectural developments in Europe in American journal Architectural Record, 'What does military design offer the architecture of peace?' Architectural Record 85 (Jan. 1939), 50-56. ${ }^{40}$ Sir Alexander Rouse's remarks are quoted at the opening of a meeting on Town Planning and Air Raids by the Basingstoke Town Planning Department, Hampshire Record Office: 12M75/DDC398, 'Town Planning and AirRaid Protection' issued by the Town Planning Department, Basingstoke, 28 Sept. 1939, 1.

${ }^{41}$ The proceedings of a meeting between a Committee of the Town Planning Institute, the ARP Department, and the Ministry of Health held in January 1937 are quoted in ibid., 1-2.
} 
continuing and unknowable threat from the air, as planning and design features were reinterpreted through the vulnerability of cities.

When war was declared, the return to shallow trenches dug in parks, windows boarded up and sandbags stacked in doorways and on street corners, revealed how, despite all the debates very little defensive architecture had made it off paper. If the fundamental question of bomb shelters remained unresolved, the importance of taking people out of the cities was demonstrated by the evacuation schemes which quickly moved 1,473,000 people away from the city-targets, along with an estimated 2,000,000 unofficial evacuees. ${ }^{42}$ The rapid movement of children, mothers and teachers in the first days of September was a central part of the government's passive defence policies against air raids, which, like the town planning policies of dispersal and decongestion, was presented as a trend for the future outside of the immediate emergency.

Reporting the start of evacuation, the Manchester Guardian stressed how that evacuation of the cities 'will become a great defensive advantage to this country in any struggle'. ${ }^{43}$ Even on the verge of the war, air raid precautions were discussed as an increasingly consistent feature in the future of Britain, a future of aerial war that was not necessarily contingent on a state of war being declared. While millions hurried away, the cities they were evacuating were left to bear the brunt of the first waves of attack. The transformation experienced by the cities would be immediate, with, in the words of the Manchester Guardian, the 'congested and dangerous districts of the East End, of Tyneside, of Clydebank', finding 'a new spaciousness'. ${ }^{44}$ In language reminiscent of planners and campaigners for social reform, anticipated air raids offered the opportunity for a policy of permanent dispersal to take root, and the oppressive density of urban living to be relieved.

The discussion of evacuation in the years before the war followed the idea that wartime emergency measures should continue to have a purpose during peace. Governmental discussions about structural precautions in planning and architecture situated peacetime works within the context of vulnerability to air attack. The need to conceive structural precautions with a dualfunctionality, both for peace and for war, in order to justify the expense and effectively prepare for the future in an era of air power, was reflected in proposals for permanent bomb shelters to be constructed under cities. The search for shelter led underground and extended the transformation of the built environment beneath the streets and buildings of the city.

\footnotetext{
42 While still a significant number it was some way short of the 3,500,000 people the government had planned to move, and indeed it was some time before the shortfall in take-up was realized, Richard Titmuss, Problems of Social Policy, $2^{\text {nd }}$ ed. (Westport, 1971), 101-102.

43 'Evacuation Begins', Manchester Guardian, 1 Sept. 1939, 8.

44 'Children of London Leave Home', Manchester Guardian, 3 Sept. 1939, 9.
} 


\section{Imagining Safety Beneath the City}

The story of huddled shelterers in London's underground network, crowded under railway bridges, in chalk caves, and elsewhere, is a key image of the 'Blitz spirit' and the effect air war had on the daily lives of civilian populations. Dietmar Süß has argued that 'the temporary dispersal of wartime society under the earth signified a massive mobilization of urban daily life'. Subterranean spaces were, he writes, 'an object of propaganda, sites for the promise of protection and the establishment of normative gender roles'. ${ }^{45}$ But they were also places dug into the heart of the city which became a part of the architecture of survival. From the open sky above the rooftops to the tunnels below the streets, the city in its entirety was transfigured into a space of citizenship, death and survival. The people submerging themselves into the city, were carrying out what Thomas Pynchon described in Gravity's Rainbow as a 'progressive knotting into' the darkened spaces of the metropolis. ${ }^{46}$ Amongst the many proposed shelter schemes, the Tecton plans for Finsbury were perhaps the most carefully devised ${ }^{47}$ Rather than considering the well-known Finsbury scheme, this section will discuss more vernacular proposals to create underground space that could have dual functions for peace and war. By doing this, it extends the argument that the perception of ordinary urban architecture was transformed in anticipation of war as architects imagined the hidden ARP infrastructure that a modern city would require in the age of air war.

After the RIBA conference on ARP in 1938, a series of correspondence to the Journal reflected how architects were re-interpreting the city's built environment. With the debate about the relative merits and dangers of different types of shelter, the more ordinary features of the city gained new significance. Fellow of the RIBA, H. Austen Hall, wrote about the potential to build pedestrian subways which could double as bomb shelters when required. ${ }^{48} \mathrm{~A}$ letter in support of his proposal stressed the dual peace and war functions of subways, and suggested that large underground shelters could be used as car parks in peacetime. ${ }^{49}$ Ideas about the potential of the road network and underground car parks to provide shelter were being discussed outside the letters pages of architectural journals; it was a topic of debate in the London County Council (LCC) both in the build-

\footnotetext{
${ }^{45}$ Dietmar Süß, 'Wartime Societies and Shelter Politics in National Socialist Germany and Britain', in Richard Overy, Claudia Baldoli and Andrew Knapp (eds), Bombing, States and Peoples in Western Europe, 1940-1945, (London, 2011), 24.

46 Thomas Pynchon, Gravity's Rainbow, (London, 2000), 3.

${ }^{47}$ For the Finsbury scheme see Meisel, 'Air Raid Shelter Policy'; John Harwood, 'The Other End of the Trajectory: Danger Zones', Grey Room 54 (2014), 80-106.

${ }^{48} \mathrm{H}$. Austen Hall, letter to the editor, Journal of the RIBA 46 (7 Nov. 1938), 43.

${ }^{49}$ S. Bylander, letter to the editor, Journal of the RIBA 46 (21 Nov. 1938), 100.
} 
up to the war, and when the bombing intensified. The images of safety underground continued to appeal to planners during the war, as subterranean space became understood through its association with safety from bombing. The metamorphosis of space extended down into the submerged networks of pipes that constituted the hidden bowels of the city.

One idea which received consideration in the build-up to war was the proposal to build large underground car parks beneath public squares in London, which would have a second use as bomb shelters. Although implausible and ultimately rejected these schemes reflect how the problems of finance and time, as bombs could fall at any moment, prompted a reappraisal of city infrastructure. John Anderson praised plans he saw for underground garages by a London firm Messrs W.W. Baldwin and Associates, in a letter to Walter Elliot, MP in November 1938. Anderson was impressed by the plans and their suitability for use as shelters, which could be built on a large scale at little or no cost to the public. These plans belonged, Anderson said, to 'the region of long-term policy', suggesting that such constructions could be beneficial to Britain long after the immediate emergency. ${ }^{50}$ The dual considerations of traffic congestion and air raid precautions seemed for a time to make these proposals popular in government. A memorandum in early November that addressed the economic issues of the schemes stated that: 'an immense aggregate of absolute Air Raid protection can be provided, together with a complete solution of the Car Parking problem, without cost to the Government or Local Authorities, and therefore without any increase in either rates or taxes. ${ }^{\prime 51}$ The underlined promise of free provision of both car parking space and public air raid shelters was eventually tempered by the technical studies, which suggested that the proposed shelters would be far too shallow to offer any meaningful protection from bombs.

One particular scheme which was discussed at length, however, was that presented by Messrs Hurst and Pierce in association with Rendel, Palmer and Tritton. The plans made particular reference to the significant sites of Leicester Square, Hanover Square, Kensington Square, and Cavendish Square. ${ }^{52}$ In his report for the LCC, architect E.P. Wheeler wrote how the proposal was being sold on the twin purpose of car parks for shoppers and theatre-goers, and their use as air raid shelters in case of emergency. He also noted that a similar plan had been put forward by Park Mechanized Parking Systems Ltd in 1935. Uncertainty about the effectiveness of shelters less than sixty feet deep, concerns about flooding from broken mains and sewers, together with anxiety about

\footnotetext{
50 TNA, Housing and Local Government (HLG) 7/42, John Anderson letter to Walter Elliot, 28 Nov. 1938.

51 TNA, HLG 7/42, W. M. Browing, 'Memorandum', 3 Nov. 1938 [underlined in original].

52 London Metropolitan Archives (LMA), London County Council (LCC), CE/WAR/1/7, Town Planning and Building Regulation Committee, 18 Jul. 1938.
} 
crowding a large number of people into a garage, meant that the scheme was not developed..$^{53}$ Proposals for remaking London's public squares into spaces permanently prepared to be transformed into bomb shelters, with minimal time needed to enact the change, reflects how local and national government perceptions of urban space were impacted upon by the anticipation of future aerial war. The arguments in favour of urban planning were expanding to include long-term security concerns.

The Thames was a strategically crucial aspect of London's defence. Discussions in the LCC before the war about the bridges and tunnels over and under the Thames reflected the importance attached to traffic flows, and also illustrated how the meaning and perception of underground space had been altered by the danger of air war. Preparations were well underway for emergency measures to ensure traffic across the river in war by the mid-1930s, with plans for temporary bridges at key sites ${ }^{54}$ In addition to the bridges, the tunnels under the Thames (most notably the Blackwall and Rotherhithe tunnels), were identified by the ARP Department as potential bomb shelters.

A plan for a new ventilation system for tunnels under the Thames was immediately interpreted by Commander A. Steele-Perkins as a device which could be used to prevent poison gas from seeping into the tunnels. The Chief Engineer T. Pierson-Frank had not envisioned tunnels as shelters, but he acknowledged in his reply to Steele-Perkins that 'it might be possible for them to be used as shelters as you suggest'. ${ }^{55}$ In 1938, however, the ARP Department confirmed that the tunnels under the Thames would be unsuitable as bomb shelters, as they were simply too liable to flooding to be seriously considered. ${ }^{56}$ However, in 1937 the Highway Development Survey of Greater London (the Bressey Report) had suggested that the new tunnel roads should be bomb proof, and permanently available as bomb shelters..$^{57}$

The development of the road networks which were essential to the continued prosperity and success of London was associated closely with protection from aerial bombardment, both in terms of physical protection under the city, and the maintenance of life, communication and production. Practical and economic difficulties, combined with continuing uncertainty about what would be required to make a tunnel or shelter truly bomb proof, severely limited the actual development of these schemes. In February 1939 the LCC Highways Committee met to discuss the use of tunnels as shelters. Of the new tunnels proposed in the Bressey Report, the Council had only proceeded with the duplication of Blackwall Tunnel, a project which was not due for completion before 1944. The

\footnotetext{
53 LMA, LCC/CE/WAR/1/7, E.P. Wheeler, 'Report by the Architect to the Council', 15 Jul. 1938, 1-3.

54 LMA, LCC/CE/WAR/1/7, Committee of Imperial Defence ARP meeting, 18 Dec. 1934.

${ }^{55}$ LMA, LCC/CE/WAR/1/7, correspondence between A. Steele-Perkins and T. Pierson-Frank, 22-23 Nov. 1935.

${ }^{56}$ LMA, LCC/CE/WAR/1/7, note from ARP department, 28 Apr. 1938.

${ }^{57}$ LMA, LCC/CE/WAR/1/14, Bressey report quoted in LCC Highways Committee meeting, 10 Feb. $1939,1$.
} 
Committee consulted with the Home Office, who informed them that emphasis was to be placed on the maintenance of traffic and communications across the city, and as such the tunnels ought not to be used as shelters. ${ }^{58}$ The government's focus on traffic flows and the economic life of the city over the potential of the material infrastructure of the city to be transformed into protective space was again apparent in the discussions of the Underground stations as shelters, and the response to the popular requisitioning of the platforms by London residents.

Following the 1938 crisis, the debate about the importance of providing shelters, while keeping the city functioning, was demonstrated in discussions about whether or not London's tube stations should be made available as public air raid shelters. A meeting was held at the Ministry of Transport in July 1939 to debate the use of the underground network in wartime. ${ }^{59}$ The main points of discussion were whether or not stations should be made available to the public as air raid shelters, and whether they should be used as first aid points. High-level representatives from the Ministry of Transport, the Home Office, the police, the Ministry of Health and the London Passenger Transport Board attended the meeting. There was disagreement about how to deal with the likely clamour for refuge in the stations, despite a broad agreement that keeping the tube functioning was a more pressing concern than use of the stations as shelters. ${ }^{60}$ The delegates at the meeting were responding to a memorandum circulated by the Chairman of the London Passenger Transport Board, Lord Albert Ashfield. Ashfield outlined the danger that damage to water and sewage pipes held for the underground network, and provided details of work carried out by the London County Council and the Metropolitan Water Board to evaluate stations and their vulnerability. ${ }^{61}$ The threat of flooding to the tube network was the primary concern and Ashfield's proposal for structural precautions to be taken to safeguard against this were supported at the meeting. The relatively straightforward provision of water-tight steel doors would enable stations to remain open and traffic to continue. The main danger to the continuing functionality of the underground network was a terrified public streaming into the stations seeking safety and thus clogging the system.

The problematic nature of Ashfield's tentative suggestion that some stations be set aside for shelters while others were held back for traffic was raised in the July meeting. The expectation that 'a panicked public would not discriminate between refuge and traffic stations' meant that such a scheme appeared unworkable, and a more flexible and pragmatic approach would be needed.

\footnotetext{
58 LMA, LCC/CE/WAR/ 1/14, LCC Highways Committee, 10 Feb. 1939, 1-4.

59 The papers relating to these discussions are found in TNA, HO 186/149.

60 TNA, HO 186/149, Minutes of meeting held on 19 Jul. 1939 at Ministry of Transport, 3-5.

61 TNA, HO 186/149, Lord Ashfield, 'Use of the Board's Tube Railways in a National Emergency', 21 Jun. 1939, 1-

2.
} 
Despite the difficulties expected in stopping stations being used as shelters, the meeting agreed that keeping the stations open to traffic was of primary importance. The suggestion that stations be used as first aid posts was dismissed quickly. ${ }^{62}$

The discussions about the use of the Underground in war illustrated both the primacy given to maintaining vital services and how urban infrastructure was recast by the fear of war. With the development of the Civil Defence Bill in 1939, another aspect of the discussion of public shelters in tube stations becomes apparent. Air raid shelters, as advanced in the 1939 Bill, were a private rather than a public matter. The situation of air raid shelters in the domestic sphere, with the provision of individual family Anderson shelters, the focus on protection in the home, and the absence of large public shelters, reflected concerns about the susceptibility of the urban population to civil unrest when under fire. ${ }^{63}$ As Susan Grayzel argues, the 'primary unit left to face the air raids remained the household'. The focus on the domestic and private sphere reflected the changed role of civilians and domestic space in war. ${ }^{64}$ The fear of crowds was an important element in the government's emphasis that civil defence should be focussed in the private sphere, as was the view that masses of people gathering in public shelters during air raids would damage productivity.

The opposition in government to the use of Underground stations as air raid shelters before the war had little impact on Londoners who responded to the nightly raids of the autumn of 1940 by seeking safety on the platforms. The material environment of London was changed by the falling bombs as spaces beneath the city metamorphosed into potential shelters, places of safety and survival. The evolution of informal underground public shelters into new secure spaces was an important part of the actual material refiguring of the city and its infrastructure as a result of air war, but it was preceded by a transformation of perceptions that had already recast the built environment into an architecture of survival.

In these debates about ARP, architecture and planning the unique dangers of air attack were reiterated and reaffirmed along with the various proposed remedies, none of which could have been said to be the ultimate means of defence from bombing. In the context of continuing uncertainty about how to protect vulnerable areas, the government had, throughout 1939, been encouraging firms in designated danger zones to consider 'permanent' evacuation while peace held. Despite the debates and the legislation, when war was declared in September of 1939 the high level of uncertainty as how to protect against bombing was matched by the persistent uncertainty with regards to when and how and the bombs would come. The debates about how the protect cities had

\footnotetext{
62 TNA, HO/186/149, Minutes of meeting held on 19 July 1939 at Ministry of Transport, 5.

63 Meisel, 'Air Raid Shelter Policy', 317.

${ }^{64}$ Grayzel, At Home and Under Fire, 147.
} 
not produced an effective architecture of defence, but the bomb-sights had been fixed upon the cities. As Terence O'Brien wrote in his official history, in September 1939 'all civilians stood for the first time in the front line and could, irrespective of age or sex, properly be called "troops",.65

\section{Conclusion}

Air Raid Precautions had a unique role in the discussions of the preparedness of Britain, and British cities, for war. The theories of air war re-designated cities as targets and prompted architects, planners and government officials to consider how to build cities that would be less vulnerable to bombing. Established planning concerns centred on congestion and poor building quality were reframed by the expectation of attacks on urban centres. Practitioners and officials speculated about the potential of underground car parks, tunnels under the Thames, and pedestrian subways to double as bomb shelters. These ideas, which were concerned with building a permanent architecture of survival into the material infrastructure of British cities, remained only ideas, ruled out quickly by practical considerations. Such failed plans demonstrate what professionals envisaged as the future face of cities before the limits of finance and politics. However, as Ortolano has argued, studies of unrealised plans have an important role to play in urban histories. They cast light upon both 'how the future was imagined' and 'how the present was managed'. ${ }^{66}$ In this case, they illustrate how an imagined future of air raids impacted upon visions of cities and urban space before war and the perceived benefits of permanent defensive structures. The proposed doubled usage of subterranean urban areas was aimed at managing the threat of air war and the demands of urban development through the same planning techniques.

The transformation of city into target was carried out first in air power theory, but these architectural and planning ideas reveal the perception of cities as targets becoming increasing fixed in civilian thought. A focus on the future of cities meant that the threat of air raids was projected forward in time indefinitely. The militarisation of civilian urban space and infrastructure, and those professionals trained in its development, reflects an important moment when conceptions of war were transformed in anticipation of conflict. The relatively small role accorded to ARP in the official military programmes of rearmament did not indicate a lack of interest in ARP, but rather demonstrated that passive defence was not something necessarily contingent to the contemporary international situation, but rather belonged to 'the region of long-term policy'. It was within a culture heavy with imagined disasters and fearful assumptions that ARP considerations were moved into the mainstream of domestic politics and planning.

\footnotetext{
${ }^{65}$ O’Brien, Civil Defence, 224, 295.

${ }^{66}$ Guy Ortolano, 'Planning the Urban Future', 482.
} 
The militarization of urban space in the twentieth century has become a major focus for research, and by highlighting some of the impacts of anticipated aerial war on perceptions of cities, this article points to an important moment in this history. ${ }^{67}$ Holford's call to plan a 'militant peace' as the 'only alternative to a barbarous war' resonates with more contemporary concerns. The fears of always imminent and yet unpredictable attacks has contributed to the development of ever more sophisticated and total defensive infrastructures in modern cities in a way which recalls Forster's description of the '1939 State'. This 'State' was not an isolated period between peace and war, but was an image of society under constant threat. 'Prepare! Prepare!' became a version of 'business as usual' before the bombs began to fall, and in this process, the distinction between planning for peace and planning for war became increasingly hard to determine.

\footnotetext{
${ }^{67}$ See for example Stephen Graham, Cities Under Siege: The New Military Urbanism (London, 2011); Deborah Cowen and Emily Gilbert (eds), War, Citizenship, Territory (New York, 2008); Stephen Graham (ed.), Cities, War and Terrorism: Towards and Urban Geopolitics (London, 2004).
} 